\title{
Safety and Effectiveness of Struvite from Black Water and Urine as a Phosphorus Fertilizer
}

\author{
Kealan Gell (Corresponding author) \\ Environmental Technology, Wageningen UR \\ PO box 8129, $6700 \mathrm{EV}$, Wageningen, the Netherlands \\ Tel: 31-684-879-784Ｅ-mail: kealan.gell@gmail.com \\ F.J.de Ruijter \\ Plant Research International, Wageningen UR \\ PO box 616, 6700 AP, Wageningen, The Netherlands \\ Tel: 31-317-480-531Ｅ-mail: frank.deruijter@wur.nl \\ P. Kuntke
}

Sub-Department of Environmental Technology, Wageningen UR, PO box 8129

6700 EV Wageningen, the Netherlands

Tel: 31-582-843-000Ｅ-mail: philipp.kuntke@wetsus.nl

M. de Graaff

Wetsus, Agora 1, PO box 1113, 8900 CC, Leeuwarden, The Netherlands

Sub-Department of Environmental Technology, Wageningen UR, PO box 8129

6700 EV Wageningen, the Netherlands

Tel: 31-617-316-696 E-mail: marthe.de.graaff@kwrwater.nl

\author{
A.L. Smit \\ Plant Research International, Wageningen UR \\ PO 616, 6700 AP, Wageningen, the Netherlands \\ Tel: 31-317-480-524 E-mail: bert.smit@wur.nl
}

Received: September 19, 2010 Accepted: October 10, 2010 doi:10.5539/jas.v3n3p67

The research was financed by the Dutch Ministry of Agriculture, Nature and Food Quality and Wetsus

\begin{abstract}
To ensure food supply, phosphorus must be recycled, for which an appealing method is using struvite fertilizer from human excreta. One struvite from black water and another from urine were assessed for safety under Dutch regulations, and for effectiveness as $\mathrm{P}$ fertilizer in a maize field experiment and a literature review. Both struvites contained $12 \% \mathrm{P}, 12 \% \mathrm{Mg}, 6 \% \mathrm{~N}$, and $0.5-1.5 \%$ of several micronutrients. Struvites did not exceed Dutch regulations for heavy metals or pathogens, and based on literature, organic toxins should be far below regulatory limits. In this study and 18 others, struvite appears to have similar effectiveness to soluble fertilizer. Early in the season, $200 \mathrm{~kg} \mathrm{P}_{2} \mathrm{O}_{5}$ ha $^{-1}$ of black water struvite and soluble phosphorus improved maize performance $(\mathrm{P}<0.05)$, however at harvest, differences in yield and biomass $\mathrm{P}$ content were not significant. Problems of $\mathrm{Mg}$ accumulation in soil can be avoided by liming and accurate fertilization. Overall, the studied struvites are safe and effective fertilizers.
\end{abstract}

Keywords: Struvite, Fertilizer, Black water, Urine, Phosphorus, Recycling, Plant availability 


\section{Introduction}

Recently, the serious environmental problems caused by phosphorus (P) pollution have been overshadowed by the rapid depletion of global $\mathrm{P}$ reserves and ensuing food security concerns (Cordell et al., 2009; Gilbert, 2009). Both concerns can be tackled by recovering and recycling P losses to the environment. Globally, P from human excreta accounts for roughly $12 \%$ of total losses and $33 \%$ of point source losses (Smit et al., 2009). Although it is possible to produce $\mathrm{P}$ fertilizers from conventional sewage, it requires large amounts of energy. On the other hand, anaerobic digestion systems that mineralize organic matter by natural processes are able to produce energy and uncontaminated fertilizers from source separated human excreta (Lettinga, 2008). One product which can be produced by both conventional sewage systems and source separated urine or black water systems is struvite, normally in the form of magnesium ammonium phosphate hexahydrate: $\mathrm{MgNH}_{4} \mathrm{PO}_{4} \cdot 6 \mathrm{H}_{2} \mathrm{O}$.

Among various $\mathrm{P}$-fertilizer products from recycled streams, struvite has advantages in simplicity of production, purity and high P-content (de-Bashan \& Bashan, 2004; Winker et al., 2009). Many high-tech options exist for the production of struvite, reviewed by Le Corre et al. (2009), and low tech options also exist, as demonstrated by a hand-powered reactor in Nepal (Tilley, 2009) or by mixing 3 parts stale urine with one part seawater at household scale (Author, personal experience).

Pure ammonia struvite $\left(\mathrm{MgNH}_{4} \mathrm{PO}_{4} \cdot 6 \mathrm{H}_{2} \mathrm{O}\right)$ is by mass $44 \%$ crystal water, $39 \%$ phosphate $\left(\mathrm{PO}_{4}\right), 10 \%$ magnesium, and $7 \%$ ammonium. While micronutrients can be beneficial in fertilizers, other classes of contaminants, including heavy metals, pathogens, and organic toxins, are restricted under Dutch fertilizer (LNV, 2008) and EU animal byproducts regulations (ABPR 1774-2002), which are the most strict in the world (Harrison et al., 1999). Before now, limited practical review of these contamination classes has been performed for struvite (Ronteltap et al., 2007a; Winker et al., 2009).

Struvite is convenient in that it may be precipitated directly as fertilizer pebbles of $5 \mathrm{~mm}$ diameter (Giesen, 1999), or small angular crystals (Abma et al., 2009) which form sticky clumps upon drying (Author, personal experience). Heating of struvite above $50{ }^{\circ} \mathrm{C}$ will lead to a simultaneous loss of water and ammonia from the struvite crystal, and at $250^{\circ} \mathrm{C}$, only $\mathrm{MgHPO}_{4}$ remains (Bhuiyan et al., 2008; Sarkar, 1991).

Struvite has been widely cited in wastewater treatment literature as a good P-fertilizer, and often as a slow-release fertilizer, however there is limited basis for this claim. Common phosphorus fertilizers can be divided into soluble forms such as triple super phosphate, and slightly soluble forms such as rock phosphate. Struvite does not readily fit into either category since it has low solubility (Ronteltap et al., 2007b) but can decompose quickly to soluble fertilizers (Cabeza Perez et al., 2009; Johnston \& Richards, 2003).

A final issue with struvite fertilizer is possible magnesium accumulation in soil. Normally, exchangeable $\mathrm{Ca}: \mathrm{Mg}$ in soil ranges anywhere from 0.5:1 to 20:1, within which crop yields are not reduced (Schulte \& Kelling, 2004). However, hydraulic conductivity and aggregate stability can suffer when $\mathrm{Ca}<<\mathrm{Mg}$ (Zhang \& Norton, 2002) as observed with Mg rich irrigation water in India (Yadav \& Girdhar, 1980) and Kazakhstan (Karimov et al., 2009), yet this issue has not been investigated in struvite literature.

The aim of this research was to investigate if: struvites meet Dutch regulations for (a) metals, (b) organic toxins and (c) pathogens; struvites perform comparably to soluble fertilizer; and

Points (i.a), (i.c), (ii) and (iii) were investigated by experiment, and points (i.b) and (ii) by extensive literature review.

\section{Materials and Methods}

\subsection{Struvite Production}

Two struvites were used in the experiments in this study.

The first (hereafter referred to as black water struvite) was produced from effluent from a Upflow Anaerobic Sludge Blanket (UASB) reactor $\left(35^{\circ} \mathrm{C}, \mathrm{HRT}=7\right.$ days) treating black water collected by vacuum toilet system from 32 houses in Sneek, The Netherlands (Zeeman et al., 2008). Struvite production involved mixing $\mathrm{MgCl}_{2}$ with black water in a continuously stirred tank $(100 \mathrm{~L})$, overflowing into a settling tank $(750 \mathrm{~L}) . \mathrm{H}_{3} \mathrm{PO}_{4}$ was added to increase ammonia removal, and $\mathrm{NaOH}$ was added to maintain a $\mathrm{pH}$ of 8.6 (Meulman et al., 2007). 14 $\mathrm{kg}$ of roughly $0.10 \mathrm{~mm}$ struvite crystals was sampled after wet storage for several months and mixed thoroughly before analysis and application.

The second (hereafter referred to as urine struvite) was produced from urine feedstock acquired by GMB Slibverwerking Tiel B.V., The Netherlands, from a hormone recovery program for pregnant mothers. Again, 
$\mathrm{MgCl}_{2}$ addition in a completely mixed crystal growth reactor was followed by a separate precipitation tank (LeAF, 2010). The roughly $0.10 \mathrm{~mm}$ struvite crystals were air dried at $40{ }^{\circ} \mathrm{C}$, and delivered in two separate batches of $10 \mathrm{~kg}$ each by GMB Tiel. The struvite had formed aggregates that were not completely destroyed by mixing before the experiment began.

\subsection{Maize Field Experiment}

The field experiment was on sandy loam soil (Typic Andosol). Phosphorus availability was low (P-Al 80 mg P $\mathrm{kg}^{-1}$ dry soil; $\mathrm{Pw} 8.2 \mathrm{mg} \mathrm{P} \mathrm{L}^{-1}$ ), partly caused by the low $\mathrm{pH}$ of the soil (4.5). Treatments included black water struvite, urine struvite, commercial triple super phosphate (TSP) and a control, in four replicates. Plot size was 4 $\mathrm{m} \times 5 \mathrm{~m}$. Each fertilizer was applied at 30 and $200 \mathrm{~kg} \mathrm{P}_{2} \mathrm{O}_{5} \mathrm{ha}^{-1}$. Struvites were mixed with water and poured evenly onto the soil surface to avoid immediate wind erosion, and granular TSP was applied dry, by machine. Immediately after application of the phosphorus fertilizers on Day 1 (April 21, 2009), the entire field was rototilled at a depth of $15 \mathrm{~cm}$, thus the average dose of fertilizer in the upper $15 \mathrm{~cm}$ was $110 \mathrm{mg}_{2} \mathrm{O}_{5} \mathrm{~kg}^{-1} \mathrm{dry}$ soil. On Day 2, maize was machine planted. According to conventional farming practices, herbicide application and irrigation were used occasionally throughout the season. On Day 15, all plots received commercial ammonium nitrate fertilizer at $100 \mathrm{~kg} \mathrm{~N} \mathrm{ha}^{-1}$, except the $200 \mathrm{~kg} \mathrm{P}_{2} \mathrm{O}_{5} \mathrm{ha}^{-1}$ doses of struvite which received $80 \mathrm{~kg}$ $\mathrm{ha}^{-1}$ to partly account for the $\mathrm{N}$ in struvite. On Days 52, 66, 80, and 92, the performance of each maize crop stand was quantified on a scale from 0 to 10 , based on visual observations. Maize crop biomass was harvested on Day 135 as 2 to $4 \mathrm{~m}$ of rows of all above ground biomass, and immediately shredded and dryed at $105{ }^{\circ} \mathrm{C}$. On Days 18 and $146,3 \mathrm{~cm}$ cores of the top $15 \mathrm{~cm}$ of soil from 6 places in each plot were taken, mixed and immediately dried at $40{ }^{\circ} \mathrm{C}$, followed by sieving at $2 \mathrm{~mm}$.

\subsection{Nutrient and Metal Analysis}

Metal, sulfur and phosphorus levels in struvite were measured by ICP-AES after dissolution of two replicate 5 gram samples of each struvite into a clear solution of $68 \% \mathrm{HNO}_{3}$. Data reported is the average of the two replicate samples. Total $\mathrm{N}$ in struvite was measured by photo spectrometer (Hach Lange, Germany) after dissolution in weak $\mathrm{H}_{2} \mathrm{SO}_{4}$. Duplicate soil samples were analyzed from each plot with $200 \mathrm{~kg} \mathrm{P}_{2} \mathrm{O}_{5}$ ha $^{-1} \mathrm{TSP}, 200$ $\mathrm{kg} \mathrm{P}_{2} \mathrm{O}_{5}$ ha $^{-1}$ black water struvite and the control. Available phosphorus was extracted from soil by standard P-Al procedure (ammonium lactate extraction), and measured by a Segmented Flow Analyzer (SFA). Actual cation exchange capacity (CEC) was determined with an un-buffered $\mathrm{BaCl}_{2}$ solution (Houba et al., 1997) and the amount of exchangeable metals ( $\mathrm{Ca}, \mathrm{Mg}, \mathrm{Na}, \mathrm{K}, \mathrm{Fe}, \mathrm{Mn}$, and $\mathrm{Al}$ ) was measured in the $\mathrm{BaCl}_{2}$ extract by ICP-AES. Duplicate samples of each plot of biomass were analyzed for Mg and P by ICP-AES following microwave destruction in $68 \% \mathrm{HNO}_{3}$.

\subsection{Pathogen Analysis}

$1.5 \mathrm{~L}$ of raw, untreated black water and $10 \mathrm{~L}$ of UASB sludge were sampled directly from Decentralized Sanitation and Reuse installation in Sneek (UASB operated at $35^{\circ} \mathrm{C}$ with 7 day hydraulic retention time), and refrigerated $\left(4{ }^{\circ} \mathrm{C}\right)$ for less than one month until analysis, at which time samples were shaken and mixed thoroughly. Pathogen analysis of struvite, black water and UASB sludge was done by dilution of $10 \mathrm{~g}$ of sample in $100 \mathrm{~mL}$ demi water in a sterile stomacher bag, and mixed for 2 minutes. Detection and enumeration of Enterobacteriaceae was done by plating each sample on six replicate plates at $37^{\circ} \mathrm{C}$ on Violet Red Bile Glucose Agar (VRBGA), based on ISO 21528, in accordance with EU Animal By-products Regulations, ABPR 1774-2002. Colonies were confirmed and identified to the species level by oxidase test, aminopeptidase test, microscopy, oxidation fermentation agar (OFA) test, and BBL Entereotubes.

\subsection{Statistical Analysis}

Averages of data across the four replicate plots of the maize experiment were compared based on their means by one way Anova test with post-hoc Tukey test by PASW SPSS software.

\subsection{Literature Review}

On two topics, data from literature has been compiled and analyzed.

The first topic is the levels of metals and persistent organic toxins in human excreta, which are relevant under fertilizer regulations. Data is expressed as milligrams of metal or organic compound per $\mathrm{kg} \mathrm{of}_{2} \mathrm{O}_{5}$, based on an average total per capita excreta stream of $2 \mathrm{~g} \mathrm{P}$ day $^{-1}$ (Heinonen-Tanski \& van Wijk-Sijbesma, 2005; Kirchmann \& Pettersson, 1995).

The second topic is plant availability studies with struvite. 19 different studies (Table 4) were found which investigated fertilizer effectiveness and/ or plant availability of P from struvite. 


\section{Results}

\subsection{Nutrient Composition and Contamination of Black water and Urine Struvite}

Both struvites had similar composition of roughly $12 \% \mathrm{P}$ and $\mathrm{Mg}$, and 0.25 to $5 \% \mathrm{~N}, \mathrm{Ca}, \mathrm{Fe}, \mathrm{S}, \mathrm{Na}$, and $\mathrm{K}$ as weight fractions of total solids (Table 1).

From literature, zinc levels in untreated human feces exceed Dutch fertilizer regulations, however metal levels in struvites were less than $15 \%$ of the maximum level in regulations (Table 2).

Raw black water contained 36200 colony forming units (CFU) per gram of enterobacteriaceae, including pathogens Klebsiella pneumoniae, Proteus mirabilis, and Enterobacter agglomerans, whereas zero enterobacteriaceae were found in either struvite. EU regulation ABPR 1774-2002 allows a maximum level of $1000 \mathrm{CFU} \mathrm{g}{ }^{-1}$ in recycled organic waste products. The sludge in the UASB reactor contained $100 \mathrm{CFU} \mathrm{g}^{-1}$, including E. Coli.

The compounds closest to legal thresholds for organic toxins were pesticides aldrin, deldrin, and DDT, as well as PAH's naphthalene and hydroxyfluorene, which were roughly 1 to $5 \%$ of fertilizer regulations (Table 3).

\subsection{P Availability to Plants and the Behavior of Struvite in the Soil}

Until halfway through the growth period (Day 66) the maize treated with black water struvite, and triple super phosphate (TSP) at $200 \mathrm{~kg} \mathrm{P}_{2} \mathrm{O}_{5}$ ha $^{-1}$ was rated significantly $(\mathrm{P}<0.05)$ better than the control, as indicated by stars in Fig. 1. Urine struvite did not produce significant improvements in maize growth, however early in the season, a dose-performance trend was apparent for all $\mathrm{P}$ fertilizers in Fig. 1. At harvest, there was no significant differences between dry matter yield (averaging 23 tonnes per hectare) and $\mathrm{P}$ uptake (averaging $70 \mathrm{~kg} \mathrm{P}_{2} \mathrm{O}_{5} \mathrm{ha}^{-1}$ ) across all treatments, which indicates $\mathrm{P}$ was not limiting maize growth in this experiment.

Fig. 2 shows phosphorus availability in the soil in TSP, black water struvite and control plots, at Days 18 and 146. Both at the beginning and the end of the season, soil amended with TSP and blackwater struvite had higher available P.

Many pot studies showed struvite treatments to perform similarly to soluble P fertilizer treatments, and not insoluble fertilizer treatments (Table 4), while one study found struvites performance was between soluble and insoluble fertilizers (Massey et al., 2009). The literature studied had three field scale experiments. These showed increases in available P after struvite application (Bridger et al., 1962; Cabeza Perez et al., 2009; DLV, 2008), but did not show differences as clearly as pot experiments. None of the studies in Table 4 indicated that struvite exceeded any regulatory limits or reduced crop growth significantly. Eight studies specifically investigated safety issues of struvite as fertilizer, and again found no intrinsic problems. Metal contamination was investigated and posed a risk from dirty feedstock in some cases (Abma et al., 2009; Escher et al., 2006; Goto, 1998; Li \& Zhao, 2003; Matsumiya et al., 2000; Schuiling \& Andrade, 1999; Ueno \& Fujii, 2001; Weinfurtner et al., 2009). One study investigated plant growth in pure struvite (Bridger et al., 1962) and another with very high doses (Li \& Zhao, 2003), and still found no problems with plant growth!

Fig. 3 shows levels of magnesium in maize and soil in plots amended with black water struvite and TSP at 200 $\mathrm{kg} \mathrm{P}_{2} \mathrm{O}_{5} \mathrm{ha}^{-1}$ and the control. Blackwater struvite at $200 \mathrm{~kg} \mathrm{P}_{2} \mathrm{O}_{5} \mathrm{ha}^{-1}$, increased Mg levels by $28 \%$ in biomass $(\mathrm{P}<0.05)$ and $100 \%$ in the soil $(\mathrm{P}<0.05)$ compared to the control and TSP plots. No significant differences were found in terms of total cation exchange capacity of the soil and levels of $\mathrm{Al}, \mathrm{Ca}, \mathrm{K}, \mathrm{Na}, \mathrm{Fe}$ and $\mathrm{Mn}$ (Tukey test, $\mathrm{P}$ $>0.10$; data not shown).

\section{Discussion}

\subsection{Nutrients and Metals in Black water and Urine Struvite}

The wide range of essential plant nutrients $(\mathrm{K}, \mathrm{Ca}, \mathrm{S}, \mathrm{Na}$ and $\mathrm{Fe}$ ) present at levels of near $1 \%$ may be a positive quality for struvite as a fertilizer, and extend the function of struvite to recycling more than just the $\mathrm{N}$ and $\mathrm{P}$.

Heavy metals do not appear to be a regulatory problem for the use of source separated human excreta struvite products as fertilizer. Heavy metals are higher in urine struvite than in blackwater struvite, probably because (1) metals are removed from blackwater in the UASB reactor preceding struvite precipitation (de Graaff, 2010), and also because, $\mathrm{H}_{3} \mathrm{PO}_{4}$ was added to precipitate more $\mathrm{NH}_{4}$ from the wastewater, and thus, metal contaminants were diluted into more struvite. Heavy metals may contaminate struvite by replacing $\mathrm{Mg}, \mathrm{NH}_{4}$ or $\mathrm{PO}_{4}$ in the crystal structure (Ronteltap et al., 2007a), or as co-precipitates, for example as sulfide salts. Because the rates of recovery of P from black water and urine are greater than 90\% (LeAF, 2010; Meulman et al., 2007), levels of heavy metals can not be concentrated to more than $111 \%$ of their original content in human excreta, per P, and therefore such struvites can be considered safe products with regard to heavy metals. 


\subsection{Pathogens in Black water and Urine Struvite}

No published literature has been found which quantifies pathogen levels in struvite, despite recent reviews highlighting the critical importance of pathogen reduction in fertilizer products from sanitation (Arthurson, 2008; Winker et al., 2009).

Pathogen levels in urine are generally very low, and therefore the lack of pathogens in urine struvite is not surprising and does not demonstrate a reduction of pathogens during struvite precipitation.

On the other hand, high levels of enterobacteriaceae levels in raw black water ( $\left.36200 \mathrm{CFU} \mathrm{g}^{-1}\right)$, do pose a risk. The $2 \log 10$ reduction (>99\%) to $100 \mathrm{CFU} \mathrm{g}^{-1}$ in UASB sludge is reasonable when compared to efficient, well mixed mesophillic digesters (Smith et al., 2005). The storage of UASB sludge for several weeks in a refrigerator may also have lead to the reduction of pathogens, and thus further analysis of pathogen reduction in these UASB reactors is recommended. Still, the undetectable levels of pathogens in the struvite indicate that further reduction of pathogens may occur during struvite precipitation.

A mechanism by which pathogens may be reduced during struvite production is exposure to high salinity during dewatering, drying and storage. Enterobacteriaceae are resistant to oxygen and ammonia but are inhibited by high salinity (Müller et al., 2006). Fecal coliform survival time decreased by $55 \%$ with each $5 \%$ increase in salinity, from a salinity of 0 to $5 \mathrm{Sm}^{-1}$ (Solic \& Krstulovic, 1992).

\subsection{Organic Toxins in Black water and Urine Struvite}

Literature values for organic toxins in human excreta indicate that levels of organic toxins in struvite will remain below Dutch fertilizer regulations. This statement relies on the assumption that substances other than human excreta, such as toxic cleaning products are not deposited in the toilet.

Other classes of organic toxins that may be of concern in fertilizers, not yet listed under regulations, include phenols, hormones, pharmaceuticals, plasticizers and other chemicals for crop protection (de Mes, 2007; Fatiadi, 1984). In the field of human health, a wide variety of herbicide, pesticide and plasticizer residues have been quantified in human intake and/or excreta (Fromme et al., 2009; Hill et al., 1995; Nasreddine \& Parent-Massin, 2002; Ye et al., 2008), however the field of wastewater treatment has focused on estrogenic pharmaceuticals and hormones (de Graaff, 2010; Maurer et al., 2006; Winker et al., 2009). Escher (2006) found that less than 1 to 4 $\%$ of the spiked hormones and pharmaceuticals in the urine feedstock were present in the struvite product, which is a better performance than a bioreactor, nanofiltration, ozonation or UV. A related study found that seven non-ionic, acidic and basic hormones and pharmaceuticals stayed in solution $>98 \%$ during struvite crystallization from urine (Ronteltap et al., 2007a). Thus, organic toxins tend not to precipitate with struvite, making struvite an attractive option for avoiding organic toxins.

In contrast to the persistent organic pollutants in Table 3, estrogenic hormones are degradable in aerobic soil with a half life of days (Scherr et al., 2008; Xuan et al., 2008). However, as the investigation of hormone mimicking compounds in wastewater is still a new area of research, there are entire classes of similar compounds which are virtually uninvestigated (Streck, 2009).

\subsection{Plant Availability of Nutrients from Struvites}

Overall, black water struvite performed similarly to triple super phosphate (TSP), increasing overall crop stand performance $(\mathrm{P}<0.05)$. These results support previous research showing that struvite performs comparably to a soluble P source such as TSP (Table 4).

The release of nutrients from urine struvite appeared to be slower than TSP and blackwater struvite, since it did not improve growth rates significantly, early in the season. This could be because struvite particles from urine were clumped together and thus had lower surface area than blackwater struvite, which may account for the slower release of nutrients. If further research indicates that this is in fact the mechanism controlling the release of mineral nutrients from the two struvites, different sizes of granules can be made easily during drying of struvite, as it has happened naturally in this case, to control the temporal pattern of nutrient release.

Struvites gave similar yields to TSP, but neither fertilizer significantly increased yield compared to the control, meaning that another factor was limiting maize growth at the end of the season (not available $\mathrm{P}$ in the soil). Therefore, no clear statements on the fertilizer value of struvite can be made, except that no negative effects were observed with struvite application.

There exists a convincing body of literature produced during the past half-century that indicates that N, P, and Mg from struvite have good plant availability across a wide range of soils and crops (Table 4). Several studies also note positive effects of magnesium availability for crops. Furthermore, no study has shown negative effects from struvite application, even with seed germination in pure struvite (Bridger et al., 1962) and struvite 
application at extremely high doses (Li \& Zhao, 2003). Thus, for plant growth, we expect further research to show that struvite can be considered a safe and effective fertilizer.

\subsection{Solubility and the Behavior of Struvite in Soil}

The high dose of $200 \mathrm{~kg} \mathrm{P}_{2} \mathrm{O}_{5}$ ha $^{-1}$ of black water struvite and TSP increased P-Al at similar magnitude, compared to the control, at both the beginning and the end of the season, comparable to a similar study by Cabeza-Perez et al. (2009) which found that TSP always yielded higher P-Al and rock phosphate always yielded lower P-Al than struvites, at harvest.

To explain and predict nutrient release from struvite in the soil, solubility of struvite must be understood. The solubility of struvite changes with $\mathrm{pH}$, temperature and ionic strength (Le Corre et al., 2009).

Struvite reached a minimum solubility of $0.040 \mathrm{mM}$ at $\mathrm{pH} 8.2$ to 8.8 (Le Corre et al., 2009) whereas at $\mathrm{pH}<5$, struvite dissolved above $1 \mathrm{mM}$ (Abbona et al., 1982), and even above $10 \mathrm{mM}$ (Borgerding, 1972 ). The range of normal $\mathrm{pH}$ in soil is from 4.5 to 8.5 , thus more acid soils will lead to quicker dissolution of struvite.

The solubility of struvite also changed dramatically with temperature, peaking at $2 \mathrm{mM}$ at about $20{ }^{\circ} \mathrm{C}$, compared to $1 \mathrm{mM}$ at 0 and $50^{\circ} \mathrm{C}$ in the same solution (Borgerding, 1972 ).

From reported $\mathrm{p} K_{\mathrm{SP}}$ 's $\left(\log\right.$ of molar solubility product) in pure water $\left(\mathrm{p} K_{\mathrm{SP}}=12.60\right)$, struvite can dissolve to $0.063 \mathrm{mM}$ (Michalowski \& Pietrzyk, 2006), whereas in urine, with ionic strength of $0.40 \mathrm{M}\left(\mathrm{p} K_{\mathrm{SP}}=13.26\right)$ struvite will dissolve to $0.038 \mathrm{mM}$ (Ronteltap et al., 2007b). The ionic strength of soil moisture is generally around $0.10 \mathrm{M}$ and thus the solubility in soil will be between these values, still depending on temperature.

Regardless of the exact solubility product, the concentrations of $\mathrm{Mg}^{2+}, \mathrm{NH}_{4}{ }^{+}$and $\mathrm{HPO}_{4}^{-}$ions in soil solution ultimately determine the dissolution of struvite, and are mainly dependent on soil type and moisture content (Dyer et al., 2008). In soil moisture, typical concentrations are 0.1 to $15 \mathrm{mM}$ Magnesium (Adams, 1971; Dyer et al., 2008), 0.01 to $1 \mathrm{mM}$ orthophosphate (Adams, 1971; Edmeades et al., 1985), and 0.01 to $100 \mathrm{mM}$ ammonium and ammonia (Edmeades et al., 1985; Smethurst et al., 2001). Thus struvite may dissolve in a typical soil, especially in soils with low ammonia levels.

Bridger et al., (1962) argues that the nitrification of ammonium often limits the dissolution of struvite. In aerobic soil, the concentration of nitrate is much higher than ammonium in solution, due to rapid conversion process from ammonia to nitrate by bacteria. This biological process is dependent on temperature, other nutrients, oxygen and microbial community composition. Further experiments with nitrification inhibitors, sterile soil, and varying temperatures support the theory that nitrification of ammonia often limits struvite dissolution (Rothbaum \& Rohde, 1976). In a fertile aerobic soil, ammonium can be converted to nitrate within days, whereas some anaerobic soils have permanently high ammonium levels in which case another process might be limiting dissolution. Thus, this mechanism can explain plant availability, as reported in Table 4.

\subsection{Magnesium Accumulation}

The $28 \%$ increase in magnesium content in the maize biomass due to struvite is not expected to have an important effect on the nutritional value of maize for humans or animals (Toba et al., 1999).

Application of magnesium $(\mathrm{Mg})$ in black water struvite at $200 \mathrm{~kg} \mathrm{P}_{2} \mathrm{O}_{5} \mathrm{ha}^{-1}$ caused a two fold change in exchangeable $\mathrm{Ca}: \mathrm{Mg}$ ratio of the soil from roughly 4:1 to 2:1 over 146 days $(\mathrm{P}<0.05)$, indicating that over several years of this rate of struvite application, the soil physical properties such as hydraulic conductivity and aggregate stability may begin to deteriorate (Zhang \& Norton, 2002).

The total cation exchange capacity (CEC) of the field plot soil of $3 \mathrm{cmol} \mathrm{kg}^{-1}$ was very low, indicating that this field had poor buffer capacity for water, $\mathrm{pH}$ and nutrients compared to most soils with CEC of 10 to $50 \mathrm{cmol} \mathrm{kg}^{-1}$ (Parfitt et al., 1995). Furthermore, in this experiment, the rate of $\mathrm{P}$ application $\left(200 \mathrm{~kg} \mathrm{P}_{2} \mathrm{O}_{5} \mathrm{ha}^{-1}\right)$ was excessive compared to the crop uptake $\left(70 \mathrm{~kg} \mathrm{P}_{2} \mathrm{O}_{5} \mathrm{ha}^{-1}\right)$. For context, a soil with $\mathrm{CEC}$ of $35 \mathrm{cmol} \mathrm{kg}^{-1}$ and struvite application rate of $50 \mathrm{~kg} \mathrm{P}_{2} \mathrm{O}_{5} \mathrm{ha}^{-1}$ would take at least 50 years to reach a 2 fold change in Ca:Mg ratio.

Plants uptake $\mathrm{P}$ and $\mathrm{Mg}$ in similar proportions to those applied by struvite. In a soil with $\mathrm{CEC}=10 \mathrm{cmol} \mathrm{kg}^{-1}$, $50 \% \mathrm{Ca}$ and $15 \% \mathrm{Mg}$, molar ratios of Mg:P for maize uptake was found to be roughly 1.3:1 to 2:1 (Estes, 1972), whereas struvite contains $\mathrm{Mg}: \mathrm{P}$ at a molar ratio of 1:1. Therefore, if struvite fertilization is not excessive on a $\mathrm{P}$ basis, it will not be excessive on a Mg basis.

Still the Ca:Mg ratio will change if Mg is added and Ca is not. Estes (1972) also found that maize uptake of Ca and $\mathrm{Mg}$ was roughly equal on a molar basis. Thus quantities of calcium must be replenished, perhaps by liming, at the same molar rate that struvite is applied to maintain a healthy $\mathrm{Ca}: \mathrm{Mg}$ ratio over the long term. 


\section{Conclusions}

Struvites from urine and anaerobically digested black water were assessed for safety and effectiveness as phosphorus fertilizers. It was found that:

- $\quad$ Both struvites contained levels of P (12\%), N (5\%) and Mg (11-14 \%) suitable for use as macronutrient fertilizer; for comparison, the $\mathrm{P}$ content of triple super phosphate is $19 \%$.

- $\quad$ Both struvites contained quantities of $\mathrm{Fe}, \mathrm{Na}, \mathrm{Ca}, \mathrm{S}$, and $\mathrm{K}$ which may supplement their value as fertilizers.

- $\quad$ Both struvites were within Dutch regulatory limits for heavy metals and pathogens, and in general, struvites produced from the same feedstock are also likely to pass these regulations.

- $\quad$ From literature, organic contamination in human excreta feedstock is $95 \%$ lower than in Dutch fertilizer regulations and less than $4 \%$ of organic contamination in the feedstock is expected to precipitate with struvite.

- $\quad$ Based on 24 studies, plant availability of $\mathrm{P}$ from struvite is often comparable to that of soluble fertilizer.

- $\quad$ No problems are expected from magnesium addition to soil by struvite, when P over-fertilization is avoided and calcium extracted by crops is replenished.

- $\quad$ Overall, the struvites studied are safe and effective P fertilizers. Based on the findings presented in this paper, the Dutch Ministry of Agriculture has indicated that it is likely to approve an application to trade similar struvite fertilizer products in the Netherlands.

\section{Acknowledgements}

This project involved Plant Research International, Wageningen University sub-department of Environmental Technology, and Wetsus. This research was financed by the Dutch Ministry of Agriculture, Nature and Food Quality and by Wetsus. This work was performed in the TTIW-cooperation framework of Wetsus, Centre of Excellence for Sustainable Water Technology (www.wetsus.nl). Wetsus is funded by the Dutch Ministry of Economic Affairs, the European Union Regional Development Fund, the Province of Fryslân, the City of Leeuwarden and the EZ/Kompas program of the "Samenwerkingsverband Noord-Nederland". Thanks to Grietje Zeeman, and Ingrid de Maas for their supervision and contributions.

\section{References}

Abbona, F., Lundager Madsen, H. E., \& Boistelle, R. (1982). Crystallization of two magnesium phosphates, struvite and newberyite: Effect of $\mathrm{pH}$ and concentration. Journal of Crystal Growth, 57(1), 6-14. doi:10.1016/0022-0248(82)90242-1, http://dx.doi.org/10.1016/0022-0248(82)90242-1

Abma, W. R., Driessen, W., Haarhuis, R., \& Loosdrecht, M. C. M. (2009). Upgrading of sewage treatment plant by sustainable \& cost-effective separate treatment of industrial wastewater. Paper presented at the IWE Nutrient Management in Wastewater Treatment Processes, 6-9 September 2009.

Adams, F. (1971). Ionic Concentrations and Activities in Soil Solutions. Soil Sci Soc Am J, 35(3), 420-426. doi:10.2136/sssaj1971.03615995003500030028x, http://dx.doi.org/10.2136/sssaj1971.03615995003500030028x

Arthurson, V. (2008). Proper Sanitization of Sewage Sludge: a Critical Issue for a Sustainable Society. Appl. Environ. Microbiol., 74(17), 5267-5275. doi:10.1128/AEM.00438-08, http://dx.doi.org/10.1128/AEM.00438-08

Bhuiyan, M. I. H., Mavinic, D. S., \& Koch, F. A. (2008). Thermal decomposition of struvite and its phase transition. Chemosphere, 70(8), 1347-1356. doi:10.1016/j.chemosphere.2007.09.056, http://dx.doi.org/10.1016/j.chemosphere.2007.09.056

Borgerding, J. (1972). Phosphate deposits in digestion systems. Journal of the Water Pollution Control Federation, 44, 813-819.

Bridger, G. L., Salutsky, M. L., \& Starostka, R. W. (1962). Micronutrient Sources, Metal Ammonium Phosphates as Fertilizers. Journal of Agricultural and Food Chemistry, 10(3), 181-188.

Cabeza Perez, R., Steingrobe, B., Romer, W., \& Claassen, N. (2009). Plant availability of P fertilizers recycled from sewage sludge and meat and bone meal in field and pot experiments. Paper presented at the IWE International Conference on Nutrient Recovery from Wastewater Streams, Vancouver, Canada, May 2009.

Cordell, D., Drangert, J.-O., \& White, S. (2009). The story of phosphorus: Global food security and food for thought. Global Environmental Change, 19(2), 292-305.

Darnerud, P. O., Atuma, S., Aune, M., Bjerselius, R., Glynn, A., Grawé, K. P., et al. (2006). Dietary intake estimations of organohalogen contaminants (dioxins, PCB, PBDE and chlorinated pesticides, e.g. DDT) based on Swedish market basket data. Food and Chemical Toxicology, 44(9), 1597-1606. 
de-Bashan, L. E., \& Bashan, Y. (2004). Recent advances in removing phosphorus from wastewater and its future use as fertilizer (1997-2003). Water Research, 38(19), 4222-4246.

de Graaff, M. (2010). Resource Recovery from Black Water. Wageningen University, Wageningen.

de Mes, T. (2007). Fate of estrogens in biological treatment of concentrated black water. Wageningen University, Wageningen.

DLV. (2008). Oriëntatie toepassingsmogelijkheden Mg-struviet als meststof in de Land-en Tuinbouw (private report, in Dutch) by B.V. Duynie and DLV Plant. Wageningen, Netherlands.

Dyer, C. L., Kopittke, P. M., Sheldon, A. R., \& Menzies, N. W. (2008). Influence of Soil Moisture Content on Soil Solution Composition. Soil Sci Soc Am J, 72(2), 355-361. doi:10.2136/sssaj2007.0124, http://dx.doi.org/10.2136/sssaj2007.0124

Edmeades, D., Wheeler, D., \& Clinton, O. (1985). The chemical composition and ionic strength of soil solutions from New Zealand topsoils. Australian Journal of Soil Research, 23(2), 151-165.

Erhardt, W., \& Prüeß, A. (2001). Organic Contaminants in Sewage Sludge for Agricultural Use. Brussels: European Commission, Joint Research Center, and UMEG.

Escher, B. I., Pronk, W., Suter, M. J. F., \& Maurer, M. (2006). Monitoring the removal efficiency of pharmaceuticals and hormones in different treatment processes of source-separated urine with bioassays. Environmental Science \& Technology, 40(16), 5095-5101.

Estes, G. O. (1972). Elemental Composition of Maize Grown Under No-Till and Conventional Tillage. Agron J, 64(6), 733-735.

Fatiadi, A. J. (1984). Priority toxic pollutants in human urine: their occurrence and analysis. Environ. Int., 10(2), 175-205.

Fromme, H., Albrecht, M., Boehmer, S., Büchner, K., Mayer, R., Liebl, B., et al. (2009). Intake and body burden of dioxin-like compounds in Germany: The INES study. Chemosphere, 76(11), 1457-1463.

Ganrot, Z., Dave, G., Nilsson, E., \& Li, B. (2007). Plant availability of nutrients recovered as solids from human urine tested in climate chamber on Triticum aestivum L. Bioresource Technology, 98(16), 3122-3129. doi:10.1016/j.biortech.2007.01.003, http://dx.doi.org/10.1016/j.biortech.2007.01.003

Ghosh, G. K., Mohan, K. S., \& Sarkar, A. K. (1996). Characterization of soil-fertilizer P reaction products and their evaluation as sources of $\mathrm{P}$ for gram (Cicer arietinum L.). Nutrient Cycling in Agroecosystems, 46(1), 71-79.

Giesen, A. (1999). Crystallisation Process Enables Environmental Friendly Phosphate Removal at Low Costs. Environmental Technology, 20(7), 769-775.

Gilbert, N. (2009). The disappearing nutrient. Nature, 461, 716-718.

Gonzalez Ponce, R., \& Lopez-de-Sa, E. G. (2007). Evaluation of struvite as a fertilizer: A comparison with traditional P sources. Agrochimica, 51(6), 301-308.

Gonzalez Ponce, R., Lopez-de-Sa, E. G., \& Plaza, C. (2009). Lettuce response to phosphorus fertilization with struvite recovered from municipal wastewater. HortScience, 44(2), 426-430.

Goto, I. (1998). Application of phosphorus recovered from sewage plants. Environmental Conservation Engineering, 27, 418-422.

Harrison, E. Z., McBride, M. B., \& Bouldin, D. R. (1999). Land application of sewage sludges: An appraisal of the US regulations. International Journal of Environment and Pollution, 11(1), 1-36. doi:10.1504/IJEP.1999.002247, http://dx.doi.org/10.1504/IJEP.1999.002247

Heinonen-Tanski, H., \& van Wijk-Sijbesma, C. (2005). Human excreta for plant production. Bioresource Technology, 96(4), 403-411. doi:10.1016/j.biortech.2003.10.036, http://dx.doi.org/10.1016/j.biortech.2003.10.036

Hill, R. H., Head, S. L., Baker, S., Gregg, M., Shealy, D. B., Bailey, S. L., et al. (1995). Pesticide Residues in Urine of Adults Living in the United States: Reference Range Concentrations. Environmental Research, 71(2), 99-108. doi:10.1006/enrs.1995.1071, http://dx.doi.org/10.1006/enrs.1995.1071

Houba, V. J. G., van der Lee, J. J., \& Novozamsky, I. (1997). Soil and Plant Analysis, Part 5B: Soil analysis procedures Wageningen, The Netherlands: Wageningen Agricultural University.

Johnston, A. E., \& Richards, I. R. (2003). Effectiveness of different precipitated phosphates as phosphorus sources for plants. Soil Use and Management, 19(1), 45-49. 
Karimov, A., Qadir, M., Noble, A., Vyshpolsky, F., \& Anzelm, K. (2009). Development of Magnesium-Dominant Soils Under Irrigated Agriculture in Southern Kazakhstan. Pedosphere, 19(3), 331-343.

Kirchmann, H., \& Pettersson, S. (1995). Human Urine - Chemical Composition and Fertilizer Use Efficiency. Fertilizer Research, 40(2), 149-154.

Kujawa-Roeleveld, K., \& Zeeman, G. (2006). Anaerobic Treatment in Decentralised and Source-Separation-Based Sanitation Concepts. Reviews in Environmental Science and Biotechnology, 5(1), 115-139.

Le Corre, K. S., Valsami-Jones, E., Hobbs, P., \& Parsons, S. A. (2009). Phosphorus Recovery from Wastewater by Struvite Crystallization: A Review. Critical Reviews in Environmental Science and Technology, 39, 433-477.

LeAF. (2010). Tiel - Fertilizer from Urine, New Sanitation Projects, Public Report: Stowa; http://www.stowa.nl/Thema_s/Nieuwe_Sanitatie.aspx.

Lettinga, G. (2008). Towards feasible and sustainable environmental protection for all. Aquatic Ecosystem Health \& Management, 11(1), 116-124.

Li, X. Z., \& Zhao, Q. L. (2003). Recovery of ammonium-nitrogen from landfill leachate as a multi-nutrient fertilizer. Ecological Engineering, 20(2), 171-181.

LNV. (2008). Regelgeving voor verhandelen van mestoffen. Retrieved. from.

Massey, M. S., Davis, J. G., Ippolito, J. A., \& Sheffield, R. E. (2009). Effectiveness of recovered magnesium phosphates as fertilizers in neutral and slightly alkaline soils. Agronomy Journal, 101(2), 323-329. doi:10.2134/agronj2008.0144, http://dx.doi.org/10.2134/agronj2008.0144

Matsumiya, Y., Yamasita, T., \& Nawamura, Y. (2000). Phosphorus Removal from Sidestreams by Crystallisation of Magnesium-Ammonium-Phosphate Using Seawater. Water and Environment Journal, 14(4), 291-296.

Maurer, M., Pronk, W., \& Larsen, T. A. (2006). Treatment processes for source-separated urine. Water Research, 40(17), 3151-3166.

McLeod, H. A., Smith, D., \& Bluman, N. (1980). Pesticide Residues in the Total Diet in Canada, V 1976 to 1978. Journal of Food Safety, 2(3), 141-164.

Meulman, B., Zeeman, G., \& Buisman, C. (2007). Treatment of concentrated blackwater on pilot scale: options and challenges. Paper presented at the International Water Association Sanitation Challenge, 19-20 May 2007, Wageningen, The Netherlands.

Michalowski, T., \& Pietrzyk, A. (2006). A thermodynamic study of struvite + water system. Talanta, 68(3), 594-601.

Montag, D., Gethke, K., \& Pinnekamp, J. (2007, June 24-27). A Feasible approach of integrating phosphate recovery as struvite at waste water treatment plants. Paper presented at the Moving Forward Wastewater Biosolids Sustainability: Technical, Managerial, and Public Synergy Moncton, New Brunswick, Canada.

Müller, T., Walter, B., Wirtz, A., \& Burkovski, A. (2006). Ammonium Toxicity in Bacteria. Current Microbiology, 52(5), 400-406.

Nasreddine, L., \& Parent-Massin, D. (2002). Food contamination by metals and pesticides in the European Union. Should we worry? Toxicology Letters, 127(1-3), 29-41.

Parfitt, R. L., Giltrap, D. J., \& Whitton, J. S. (1995). Contribution of organic matter and clay minerals to the cation exchange capacity of soils. Communications in Soil Science and Plant Analysis, 26(9), 1343 - 1355.

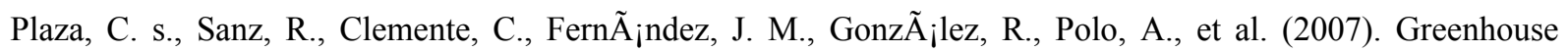
Evaluation of Struvite and Sludges from Municipal Wastewater Treatment Works as Phosphorus Sources for Plants. Journal of Agricultural and Food Chemistry, 55(20), 8206-8212.

Ponce, R. G., \& Lopez-de-Sa, E. G. (2008). Efficacy of magnesium ammonium phosphate recovered from wastewater on white lupin plant. A greenhouse experiment. Agrochimica, 52(6), 352-359.

Romer, W. (2006). Plant availability of P from recycling products and phosphate fertilizers in a growth-chamber trial with rye seedlings. Journal of Plant Nutrition and Soil Science, 169(6), 826-832.

Ronteltap, M., Maurer, M., \& Gujer, W. (2007a). The behaviour of pharmaceuticals and heavy metals during struvite precipitation in urine. Water Research, 41(9), 1859-1868.

Ronteltap, M., Maurer, M., \& Gujer, W. (2007b). Struvite precipitation thermodynamics in source-separated urine. Water Research, 41(5), 977-984. 
Rothbaum, H. P., \& Rohde, A. G. (1976). Long term leaching of nutrients from magnesium ammonium phosphate at various temperatures. New Zealand Journal of Experimental Agriculture, 4, 405-413.

Sarkar, A. K. (1991). Hydration/ dehydration characteristics of struvite and dittmarite pertaining to magnesium ammonium phosphate cement systems. Journal of Material Science, 26, 2514-2518. doi:10.1007/BF01130204, http://dx.doi.org/10.1007/BF01130204

Scherr, F. F., Sarmah, A. K., Di, H. J., \& Cameron, K. C. (2008). Modeling degradation and metabolite formation kinetics of estrone-3-sulfate in agricultural soils. Environmental Science and Technology, 42(22), 8388-8394.

Schuiling, R. D., \& Andrade, A. (1999). Recovery of Struvite from Calf Manure. Environmental Technology, 20, 765-768.

Schulte, E. E., \& Kelling, K. A. (2004). Soil calcium to magnesium ratios - Should you be concerned? Madison, Wisconsin, USA.

Smethurst, P. J., Herbert, A. M., \& Ballard, L. M. (2001). Fertilization Effects on Soil Solution Chemistry in Three Eucalypt Plantations. Soil Sci Soc Am J, 65(3), 795-804.

Smit, A. L., Bindraban, P. S., Schroder, J. J., Conijn, J. G., \& van der Meer, H. G. (2009). Phosphorus in agriculture: global resources, trends and developments: report to the Steering Committee Technology Assessment of the Ministery of Agriculture, Nature and Food Quality, The Netherlands Wageningen: Plant Research International; http://www.mvo.nl/Portals/0/duurzaamheid/biobrandstoffen/nieuws/2009/11/12571.pdf.

Smith, S. R., Lang, N. L., Cheung, K. H. M., \& Spanoudaki, K. (2005). Factors controlling pathogen destruction during anaerobic digestion of biowastes. Waste Management, 25(4), 417-425. doi:10.1016/j.wasman.2005.02.010, http://dx.doi.org/10.1016/j.wasman.2005.02.010

Solic, M., \& Krstulovic, N. (1992). Separate and combined effects of solar radiation, temperature, salinity, and $\mathrm{pH}$ on the survival of faecal coliforms in seawater. Marine Pollution Bulletin, 24(8), 411-416. doi:10.1016/0025-326X(92)90503-X, http://dx.doi.org/10.1016/0025-326X(92)90503-X

Streck, G. (2009). Chemical and biological analysis of estrogenic, progestagenic and androgenic steroids in the environment. TrAC - Trends in Analytical Chemistry, 28(6), 635-652. doi:10.1016/j.trac.2009.03.006, http://dx.doi.org/10.1016/j.trac.2009.03.006

Terman, G. L., \& Taylor, A. W. (1965). Sources of Nitrogen and Phosphorus, Crop Response to Nitrogen and Phosphorus in Metal Ammonium Phosphates. Journal of Agricultural and Food Chemistry, 13(6), 497-500. doi:10.1021/jf60142a003, http://dx.doi.org/10.1021/jf60142a003

Tilley, E., Gantenbein, B., Khadka, R., Zurbrügg, C. and Udert, K.M. (2009). In: . (2009). Social and economic feasibility of struvite recovery from uine at the community level in Nepal. Paper presented at the International Conference on Nutrient Recovery from Wastewater Streams. , London.

Toba, Y., Masuyama, R., Kato, K., Takada, Y., Aoe, S., \& Suzuki, K. (1999). Effects of dietary magnesium level on calcium absorption in growing male rats. Nutrition Research, 19(5), 783-793.

Ueno, Y., \& Fujii, M. (2001). Three Years Experience of Operating and Selling Recovered Struvite from Full-Scale Plant. Environmental Technology, 22(11), 1373 - 1381. doi:10.1080/09593332208618196, http://dx.doi.org/10.1080/09593332208618196

UNEP. (2001). Text of the Stockholm Convention on Persistant Organic Pollutants. Retrieved. from.

Van Rooij, J. G. M., Veeger, M. M. S., Bodelier-Bade, M. M., Scheepers, P. T. J., \& Jongeneelen, F. J. (1994). Smoking and dietary intake of polycyclic aromatic hydrocarbons as sources of interindividual variability in the baseline excretion of 1-hydroxypyrene in urine. International Archives of Occupational and Environmental Health, 66(1), 55-65. doi:10.1007/BF00386580, http://dx.doi.org/10.1007/BF00386580

Weinfurtner, K., Gath, S. A., Kordel, W., \& Waida, C. (2009). Ecological testing of products from phosphorous recovery processes - first results. Paper presented at the International Conference on Nutrient Recovery from Wastewater Streams.

Winker, M., Vinnerås, B., Muskolus, A., Arnold, U., \& Clemens, J. (2009). Fertiliser products from new sanitation systems: Their potential values and risks. Bioresource Technology, 100(18), 4090-4096. doi:10.1016/j.biortech.2009.03.024, http://dx.doi.org/10.1016/j.biortech.2009.03.024

Xuan, R., Blassengale, A. A., \& Wang, Q. (2008). Degradation of estrogenic hormones in a silt loam soil. Journal of Agricultural and Food Chemistry, 56(19), 9152-9158. doi:10.1021/jf8016942, http://dx.doi.org/10.1021/jf8016942 
Yadav, J., \& Girdhar, I. (1980). Effect of varying $\mathrm{Mg} / \mathrm{Ca}$ ratio and electrolyte concentration in the irrigation water on the soil properties and growth of wheat. Plant and Soil, 56(3), 413-427. doi:10.1007/BF02143035, http://dx.doi.org/10.1007/BF02143035

Ye, X., Pierik, F. H., Hauser, R., Duty, S., Angerer, J., Park, M. M., et al. (2008). Urinary metabolite concentrations of organophosphorous pesticides, bisphenol A, and phthalates among pregnant women in Rotterdam, the Netherlands: The Generation R study. Environmental Research, 108(2), 260-267. doi:10.1016/j.envres.2008.07.014, http://dx.doi.org/10.1016/j.envres.2008.07.014

Yetilmezsoy, K., \& Sapci-Zengin, Z. (2009). Recovery of ammonium nitrogen from the effluent of UASB treating poultry manure wastewater by MAP precipitation as a slow release fertilizer. Journal of Hazardous Materials, 166(1), 260-269. doi:10.1016/j.jhazmat.2008.11.025, http://dx.doi.org/10.1016/j.jhazmat.2008.11.025

Zeeman, G., Kujawa, K., de Mes, T., Hernandez, L., de Graaff, M., Abu-Ghunmi, L., et al. (2008). Anaerobic treatment as a core technology for energy, nutrients and water recovery from source-separated domestic waste(water). Water Science and Technology, 57(8), 1207-1212. doi:10.2166/wst.2008.101, http://dx.doi.org/10.2166/wst.2008.101

Zhang, X. C., \& Norton, L. D. (2002). Effect of exchangeable Mg on saturated hydraulic conductivity, disaggregation and clay dispersion of disturbed soils. Journal of Hydrology, 260(1-4), 194-205. doi:10.1016/S0022-1694(01)00612-6, http://dx.doi.org/10.1016/S0022-1694(01)00612-6

Table 1. Main components of urine and black water struvites, as a weight fraction of total solids (TS)

\begin{tabular}{|l|l|l|}
\hline & Blackwater & Urine \\
\hline & Struvite & Struvite \\
\hline & (\% of TS $)$ & $(\%$ of TS $)$ \\
\hline $\mathrm{P}$ & 11.91 & 11.66 \\
\hline $\mathrm{Mg}$ & 10.68 & 13.97 \\
\hline $\mathrm{N}$ & 5.38 & 5.26 \\
\hline $\mathrm{Ca}$ & 1.37 & 0.96 \\
\hline $\mathrm{Fe}$ & 0.74 & 0.48 \\
\hline $\mathrm{K}$ & 0.41 & 0.24 \\
\hline $\mathrm{Na}$ & 0.87 & 0.51 \\
\hline $\mathrm{S}$ & 0.98 & 0.74 \\
\hline
\end{tabular}

Table 2. Levels of heavy metals in raw human excreta, black water and urine struvite, other struvites from literature, and Dutch fertilizer regulations (in $\mathrm{mg} \mathrm{kg}^{-1} \mathrm{P}_{2} \mathrm{O}_{5}$ )

\begin{tabular}{|l|l|l|l|l|l|l|l|}
\hline & Human & Human & Struvite & Struvite & Struvite & Struvite & Fertilizer \\
\hline & Urine & Feces & Urine & Blackwater & Potatoes & Sewage & Regulation \\
\hline $\mathrm{Cd}$ & 3 & 15 & $<6$ & $<4$ & 0.9 & 0.2 & 31.3 \\
\hline $\mathrm{Cr}$ & 13 & 29 & $<6$ & $<4$ & 17 & $<677$ & 1875 \\
\hline $\mathrm{Cu}$ & 169 & 1595 & 336 & 134 & 42 & & 1875 \\
\hline $\mathrm{Ni}$ & 126 & 108 & 6 & $<2$ & 26 & $<31140$ & 750 \\
\hline $\mathrm{Pb}$ & 20 & 29 & $<81$ & $<59$ & 6.6 & $<0.17$ & 2500 \\
\hline $\mathrm{Zn}$ & 291 & 15551 & 841 & $<59$ & 336 & $<338$ & 7500 \\
\hline $\mathrm{Hg}$ & 1 & 13 & & & $<0.3$ & & 18.8 \\
\hline $\mathrm{As}$ & & & $<42$ & $<24$ & $<6$ & 2 & 375 \\
\hline $\mathrm{Refs}$. & {$[1]$} & {$[2]$} & {$[3]$} & {$[3]$} & {$[4]$} & {$[5]$} & {$[6]$} \\
\hline
\end{tabular}

Refs: [1] - (Ronteltap et al., 2007a), [2] - (Kujawa-Roeleveld \& Zeeman, 2006), [3] - this study, [4] - (Abma et al., 2009), [5] - (Ueno \& Fujii, 2001), [6] - (LNV, 2008) 
Table 3. Levels of organic contaminants in raw human excreta which are specifically restricted by Dutch fertilizer legislation. Organic contaminants in raw human excreta as restricted by Dutch fertilizer legislation, EU and global restrictions and observed values from literature

\begin{tabular}{|l|l|l|l|l|l|l|}
\hline Organic Compound & \multicolumn{2}{l|}{ Contamination Rate (in $\mathrm{mg} \mathrm{kg}^{-1} \mathrm{P}_{2} \mathrm{O}_{5}$ ) } & \multicolumn{2}{l|}{ Restrictions } \\
\hline & Regulation & Excreta & Urine & Urine & & \\
\hline & Netherlands & Sweden & Canada & Italy & EU & Global \\
\hline HCB, hexachlorobenzene & 31 & 0.025 & 0.102 & & EU & SC \\
\hline$\Sigma$ HCHs & 310 & 0.018 & & & & \\
\hline$\gamma$-HCH (Lindane) & 1.2 & & & & EU & SC \\
\hline$\Sigma$ aldrin/ deldrin & 7 & & 0.152 & & & SC \\
\hline$\Sigma$ endrin/isodrin & 7 & & 0.076 & & & SC \\
\hline$\Sigma$ DDT/DDD/DDE & 23 & 0.114 & 0.991 & & EU & SC \\
\hline$\Sigma$ PCDD/PCDF (Dioxin) & 0.019 & $1.19 \mathrm{E}-05$ & & & EU & SC \\
\hline$\Sigma 6$ PCB (excl PCB 118) & 375 & 0.134 & 0.381 & & EU & SC \\
\hline$\Sigma 10$ PAK (PAHs) & 11500 & & & & EU & SC \\
\hline PAH naphthalene & 600 & & & 13.43 & EU & SC \\
\hline PAH hydroxyfluorene & 270 & & & 2.42 & EU & SC \\
\hline PAH hydroxyphenanthren & 750 & & & 0.73 & EU & SC \\
\hline Minerale oil & 935000 & & & & & \\
\hline Refs. & {$[1]$} & {$[2]$} & {$[3]$} & {$[4]$} & {$[5]$} & {$[6]$} \\
\hline
\end{tabular}

Refs: [1] - (LNV, 2008), [2] - (Darnerud et al., 2006), [3] - (McLeod et al., 1980), [4] - high exposure asphalt workers (Van Rooij et al., 1994), [5] - (Erhardt \& Prüeß, 2001), [6] - Stockholm Convention on POPs (UNEP, 2001)

Table 4. List of experiments reporting the fertilizer value of struvite

\begin{tabular}{|c|c|c|c|c|c|c|c|}
\hline Citation & Year & Type & Crop & Struvite Source & \multicolumn{3}{|c|}{ Improvement in crop* } \\
\hline (Bridger et al.) & 1962 & pot & $\begin{array}{l}\text { Herbaceous flowers, } \\
\text { tomatoes }\end{array}$ & USA, chemical reagents & $0-100$ & NR & SOL \\
\hline (Bridger et al.) & 1962 & field & Shrubs, grasses & USA, chemical reagents & $40-75$ & NR & \\
\hline (Terman \& Taylor) & 1965 & pot & Maize & USA, chemical reagents & 40 & SS & \\
\hline (Ghosh et al.) & 1996 & pot & Chickpea, gram & India, chemical reagents & 50 & SS & SOL \\
\hline (Goto) & 1998 & pot & $\begin{array}{l}\text { Komatsuna, green } \\
\text { vegetable }\end{array}$ & Japan, "recovered" struvite & 50 & SS & SOL \\
\hline (Johnston \& Richards) & 2003 & pot & Ryegrass & UK, chemical reagents & 100 & SS & SOL \\
\hline (Johnston \& Richards) & 2003 & pot & Ryegrass & $\begin{array}{l}\text { Japanese sewage, and Dutch } \\
\text { sewage \& manure }\end{array}$ & 100 & SS & SOL \\
\hline (Johnston \& Richards) & 2003 & pot & Ryegrass & $\begin{array}{l}\text { Spanish red dye liquor, US } \\
\text { corn liquor }\end{array}$ & 100 & SS & SOL \\
\hline (Li \& Zhao) & 2003 & pot & Cabbage, chard, spinach, etc & Hong Kong, landfill leachate & $>100$ & SS & \\
\hline (Romer) & 2006 & pot & Ryegrass & German and USA manure & $>100$ & SS & SOL \\
\hline (Romer) & 2006 & pot & Ryegrass & $\begin{array}{l}\text { German, Italian, and Japanese } \\
\text { sewage }\end{array}$ & $>100$ & SS & SOL \\
\hline $\begin{array}{l}\text { (Gonzalez Ponce \& } \\
\text { Lopez-de-Sa) }\end{array}$ & 2007 & pot & Perennial ryegrass & Spain, municipal wastewater & & SS & $>\mathrm{SOL}$ \\
\hline (Montag et al.) & 2007 & pot & unspecified & Germany, sewage sludge & & NR & SOL \\
\hline (Plaza et al.) & 2007 & pot & Ryegrass & Spain, municipal wastewater & $>100$ & SS & SOL \\
\hline (Ganrot et al.) & 2007 & pot & Wheat & $\begin{array}{l}\text { Sweden, human urine, also } \\
\text { included zeolites }\end{array}$ & $30-100$ & SS & \\
\hline (Ponce \& Lopez-de-Sa) & 2008 & pot & White lupine & Spain, municipal wastewater & & NR & SOL \\
\hline (Cabeza Perez et al.) & 2009 & pot & Maize & Germany, sewage sludge & $25-100$ & SS & $\mathrm{SOL}$ \\
\hline (Cabeza Perez et al.) & 2009 & field & Rapeseed and winter barley & Germany, sewage sludge & $0-40$ & NS & SOL \\
\hline (DLV) & 2009 & field & $\begin{array}{l}\text { Flowers, potatoes, Brussels } \\
\text { sprouts }\end{array}$ & Netherlands, potato wastewater & & NR & \\
\hline (Massey et al.) & 2009 & pot & Spring wheat & $\begin{array}{l}\text { USA, dairy waste and process } \\
\text { wastewater }\end{array}$ & $<25$ & SS & $<\mathrm{SOL}$ \\
\hline (Gonzalez Ponce et al.) & 2009 & pot & Lettuce & Spain, municipal wastewater & & SS & SOL \\
\hline (Weinfurtner et al.) & 2009 & pot & Maize & Germany, sewage sludge & $20-100$ & SS & SOL \\
\hline $\begin{array}{l}\text { (Yetilmezsoy \& } \\
\text { Sapci-Zengin) }\end{array}$ & 2009 & pot & Purslane, cress, grass & $\begin{array}{l}\text { Turkey, digested poultry } \\
\text { manure }\end{array}$ & $>100$ & NR & \\
\hline (This study) & 2010 & field & Maize & $\begin{array}{l}\text { Netherlands, urine and black } \\
\text { water }\end{array}$ & $<30$ & NS & SOL \\
\hline
\end{tabular}

* Number refers to \% improvement over control in P-uptake and/or yield; SS = improvement is statistically significant; $\mathrm{NS}=$ improvement is not statistically significant; $\mathrm{NR}=$ statistics not reported; $\mathrm{SOL}=$ comparable to soluble fertilizer. 


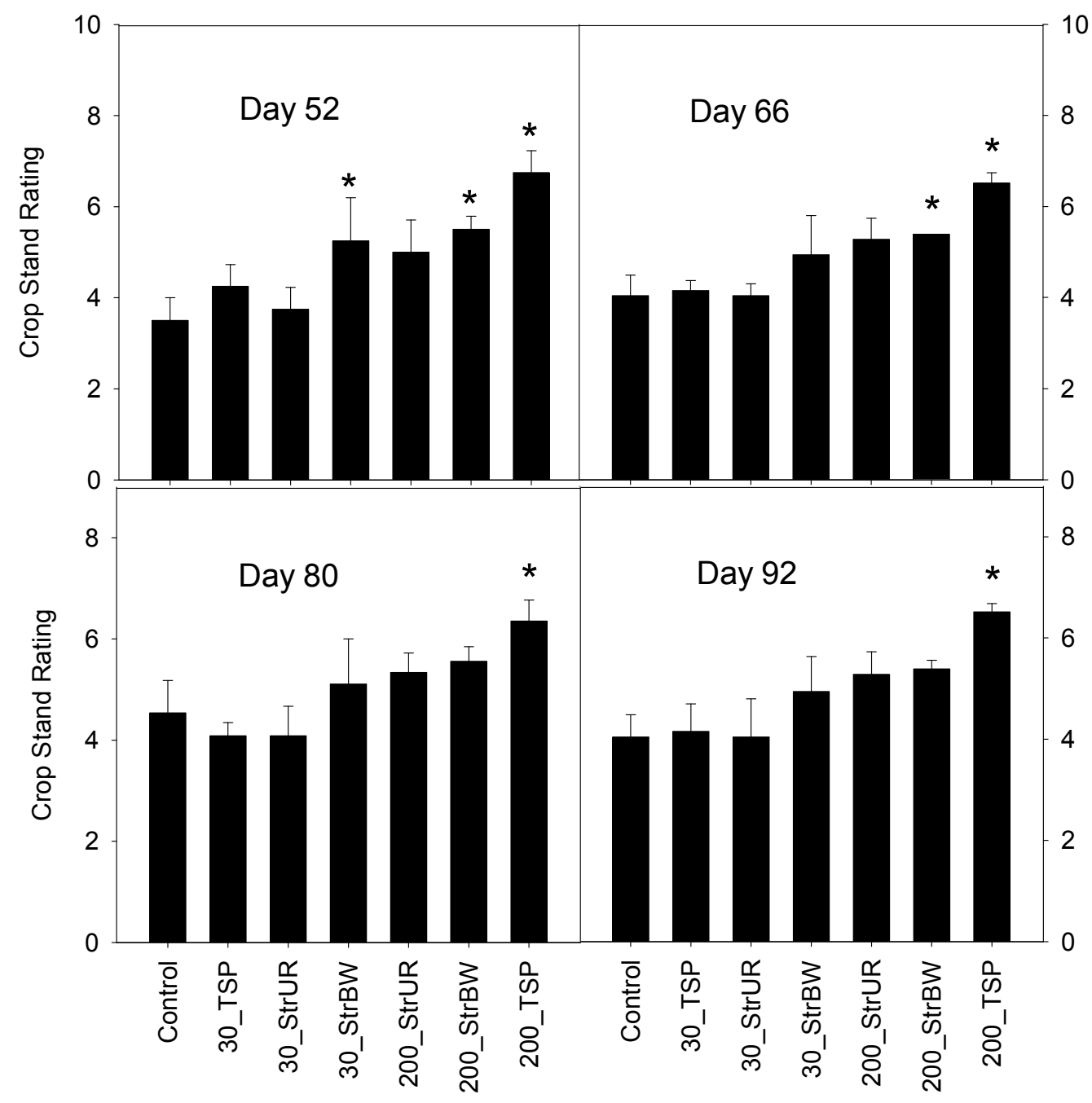

Figure 1. General crop stand evaluation from visual inspection, over the growth period for struvite and TSP plots. Error bars indicate standard error, $\mathrm{n}=4$; ${ }^{*}$ stars indicate significant difference over the control, Tukey $(\mathrm{P}<0.05)$; TSP refers to triple super phosphate, StruBW and StruUR refer to blackwater and urine struvite respectively; 30 and 200 refer to fertilizer dose in $\mathrm{kg} \mathrm{P}_{2} \mathrm{O}_{5}$ per ha 


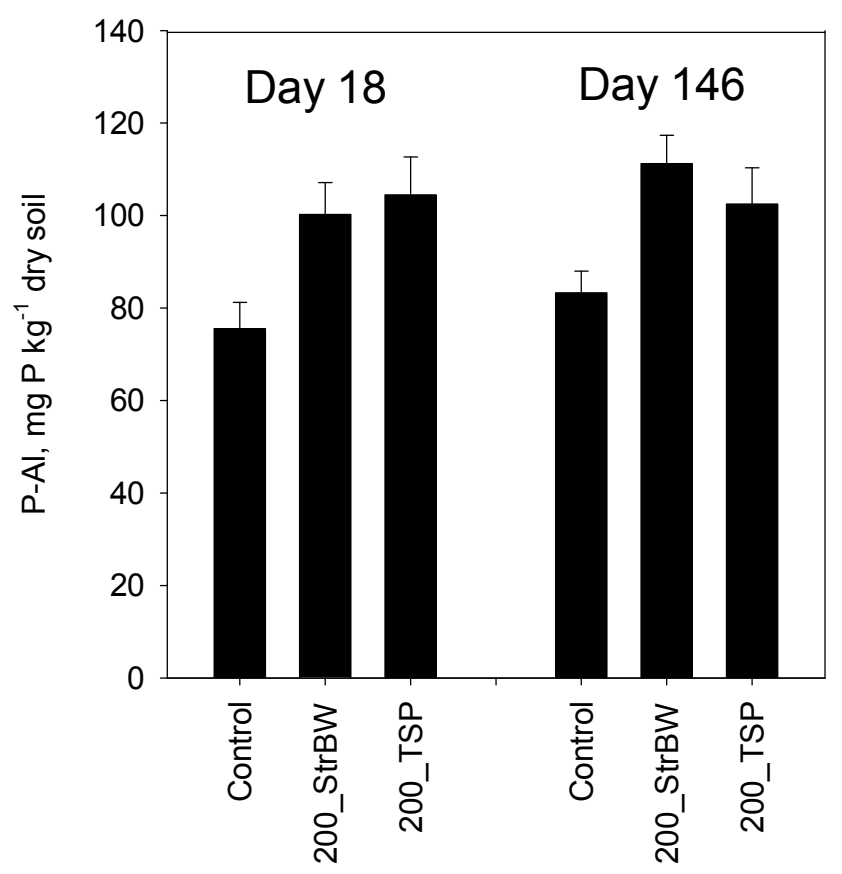

Figure 2. Soil available phosphorus (P-Al) at Days 18 and 146 for control, black water struvite, and triple super phosphate (TSP) treatments. Error bars indicate standard error, $n=4$, there were no significant differences (Tukey, $\mathrm{P}<0.05$ ) ; TSP refers to triple super phosphate, StruBW and StruUR refer to blackwater and urine struvite respectively; 200 refers to fertilizer dose in $\mathrm{kg} \mathrm{P}_{2} \mathrm{O}_{5}$ per ha

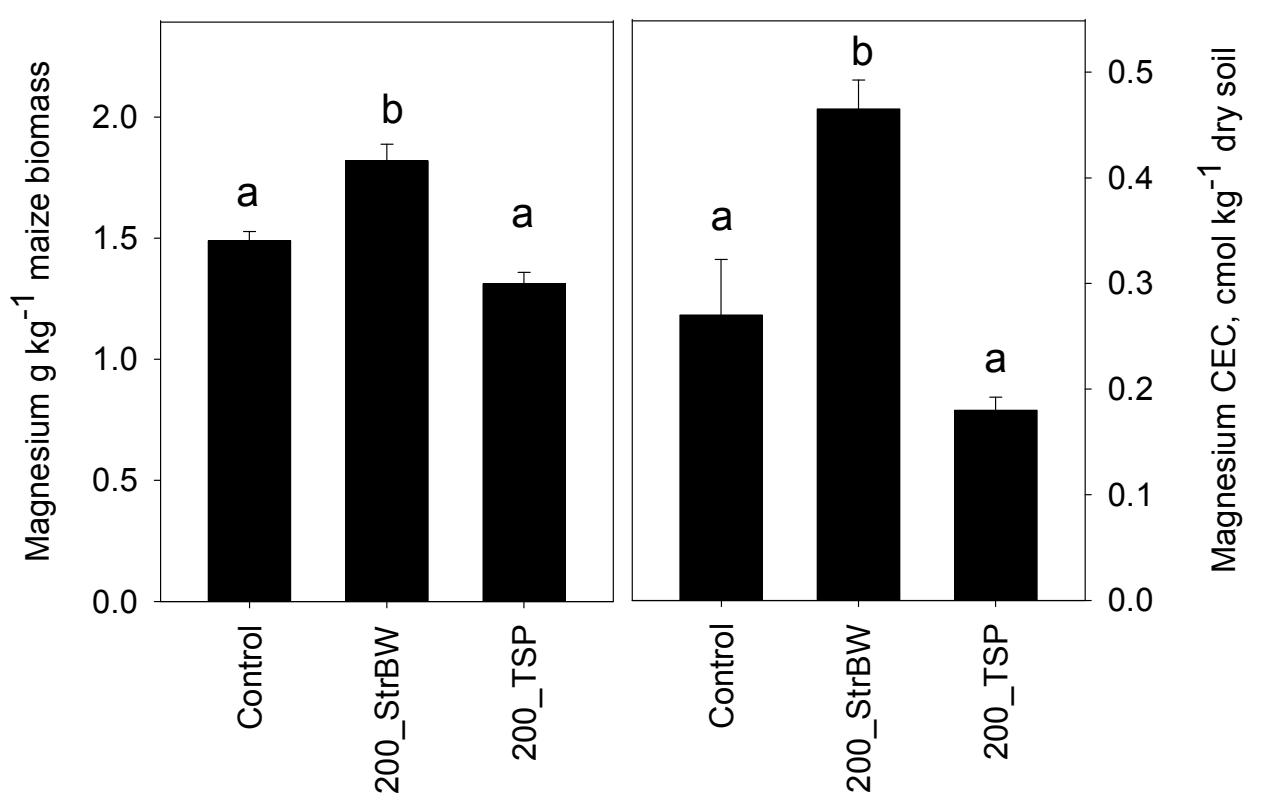

Figure 3. Magnesium levels in maize biomass (left) and soil (right) at the end of the season, Day 146. Error bars indicate standard error, $\mathrm{n}=4$; letters indicate significant differences, (Tukey $\mathrm{P}<0.05$ ); TSP refers to triple super phosphate, StruBW and StruUR refer to blackwater and urine struvite respectively; 200 refers to fertilizer dose in $\mathrm{kg} \mathrm{P}_{2} \mathrm{O}_{5}$ per ha 